Notes and miscellanea

\section{Urinary mercury excretion in dental personnel}

\author{
G. R. KELMAN \\ From the Employment Medical Advisory Service, \\ 33 Millstone Lane, Leicester
}

The potential health hazard in the extensive use of mercury in dental surgeries is a current cause for concern (Journal of the American Dental Association, 1971; Central Unit on Environmental Pollution, 1976), exacerbated by the sporadic occurrence of clinical mercury poisoning in dentists and their assistants (Cook and Yates, 1969; Iyer et al., 1976; Mantyla and Wright, 1976; Merfield et al., 1976). This paper reports the results of a survey of urinary mercury excretion in 62 Area Health Authority (AHA) and 49 National Health Service (NHS) dentists and dental surgery assistants (DSAs).

\section{The process}

Amalgam fillings were introduced into dentistry in the early nineteenth century, when they consisted simply of a mixture of metallic mercury and silver dust obtained by filing silver coins. Nowadays they are composed of a mixture of metallic mercury and a silver/tin alloy which usually also contains small quantities of copper and zinc. When the alloy and mercury are intimately mixed, formerly in a pestle and mortar, but now usually in a mechanical mixer which shakes the mixture vigorously inside a closed capsule, they form a plastic mass which is compacted into the prepared dental cavity. The amalgam then sets hard within minutes, although the filling continues to gain strength over at least 24 hours.

The ideal proportion of mercury and alloy in the final filling is roughly 50:50, although it is usual to add an excess of mercury to the initial mix. This excess is then squeezed out though a cloth before insertion of the filling. Skin contamination during the squeezing-out process can be avoided by surrounding the cloth by an impervious fingerstall. The need to expel excess mercury by hand is reduced by the

Received for publication 14 December 1977 Accepted for publication 18 January 1978 use of modern mechanical mixers; indeed, some dispense the correct amounts of mercury and alloy automatically and thus eliminate the squeezing process entirely. However, high-speed mechanical amalgamators may still cause environmental contamination (Nixon and Rowbotham, 1971), and the shaking to which they subject the mercury heats it by internal friction and so tends to cause increased vaporisation (Schneider, 1974).

Mercury absorption occurs via the lung, and to a lesser extent through the intact skin. Mercury vapour is almost completely absorbed through the alveolar membrane (Vostal and Clarkson, 1973). No more than $0.01 \%$ of ingested metallic mercury is absorbed (Central Unit on Environmental Pollution, 1976). Metallic mercury has a relatively high vapour pressure at room temperature, and appreciable vaporisation can occur into the atmosphere from spilled mercury, or from mercury which is not kept in a closed container or under water. Atmospheric contamination with mercury can also occur during the drilling out of old amalgam fillings, a process which not only vaporises mercury by heat but also produces a mercurial dust with the majority of particles within the respirable range (Buchwald, 1972).

\section{Methods}

THE SAMPLE

The investigation was made on a total of $17 \mathrm{AHA}$ and 16 NHS dental clinics in Leicestershire. The former comprised all AHA clinics in the area; the latter were chosen using a table of random numbers from a list of 88 local practices. AHA personnel comprised 28 dentists and 34 DSAs; NHS personnel consisted of 21 dentists and 28 DSAs. The members of one NHS practice declined our invitation to take part in the investigation, leaving 15 participating practices.

In addition to providing chairside assistance for the dentist, one of the chief duties of a DSA is mixing amalgam fillings. AHA dental auxiliaries and dental hygienists were included with the dentists rather than with the DSAs as their duties do not normally include mixing of amalgam.

\section{ANALYTICAL TECHNIQUE}

Early morning urine samples were collected into mercury-free containers and analysed for inorganic mercury by the Health and Safety Executive's Occupational Medicine Laboratory, 403-405 Edgware Road, London NW2, using a cold vapour atomic-absorption technique as described by Magos 
and Cernik (1969). The lower limit of sensitivity of this method is $25 \mathrm{nmol} / 1(5 \mu \mathrm{g} / \mathrm{l})$.

\section{Results}

Table 1 gives a summary of the results. In both groups of workers the DSAs had a higher mean and greater range of urinary mercury concentrations than the dentists; the NHS workers had similarly, in both dentists and DSAs, a higher mean and greater range of concentrations. Analysis of variance (after logarithmic transformation of the results to eliminate skew) indicates that these differences are just statistically significant at the $5 \%$ level $(\mathrm{F}=2 \cdot 81$, $P \simeq 0.05$ ).

With skewed data of this type the usual statistical tests, such as Student's $t$ test, cannot be applied directly, and it is often simpler to look instead at the proportion of the results which exceed certain cut-off levels. This has been done in the table for both $\mathbf{1 5 0}$ $\mathrm{nmol} / \mathrm{l}(30 \mu \mathrm{g} / \mathrm{l})$, the upper limit of normal for nonexposed workers (see discussion), and $500 \mathrm{nmol} / \mathrm{l}$ $(100 \mu \mathrm{g} / \mathrm{l})$. The proportion of personnel in which the urinary mercury concentration exceeded $150 \mathrm{nmol} / \mathrm{l}$ was $8 / 62(12.9 \%)$ in the AHA practices and 13/49 $(26.5 \%)$ in the NHS practices (not statistically significant); for a cut-off value of $500 \mathrm{nmol} / 1$ the figures were $0 / 62$ and $5 / 49(10 \cdot 2 \%)$, respectively, a statistically significant difference $\left(\chi^{2}=4.32 ; 0.01<P<\right.$ 0.05). A similar comparison of dentists and DSAs shows a statistically significant difference with a cut-off of $150 \mathrm{nmol} / \mathrm{l}$ (dentists $4 / 49(8 \cdot 2 \%)$, DSAs $17 / 62$ . $\left.(27.4 \%), \chi^{2}=4.62 ; 0.01<\mathrm{P}<0.05\right)$ but not with a cut-off of $500 \mathrm{nmol} / 1(1 / 49$ dentists $(2.0 \%)$ compared with $4 / 62$ DSAs $(6.4 \%)$; not statistically significant).

The pooled AHA and NHS results are shown in Figures 1 and 2. The practice averages are similarly -shown in Figure 3. The frequency distribution of AHA practice averages did not differ significantly from the NHS values.

\section{Discussion}

There is considerable diurnal variation in the urinary mercury concentration (Molyneux, 1966) and to

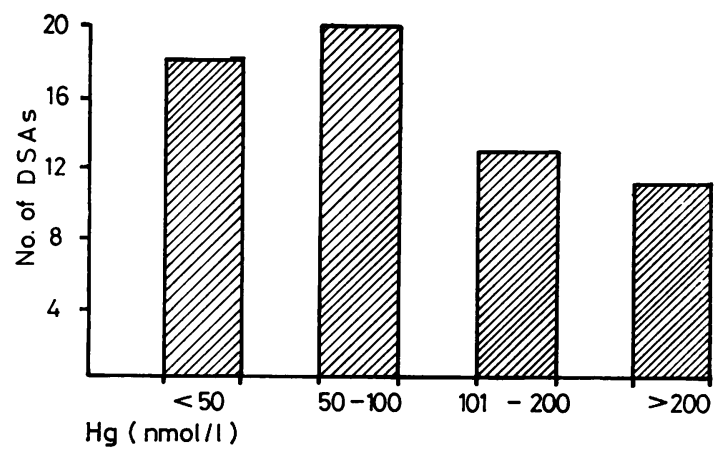

Fig. 1 Urinary mercury concentrations: DSAs.

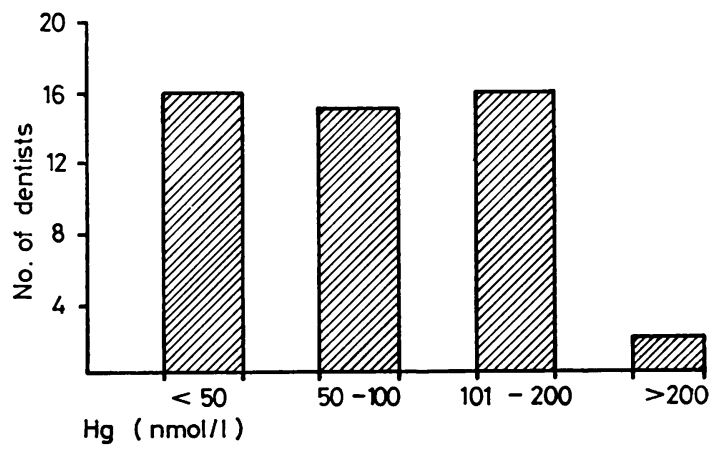

Fig. 2 Urinary mercury concentrations: dentists.

minimise the effects of this our measurements were on early morning samples, a practice adopted by most other investigators. The mean specific gravity of the samples was 1.021, a figure which suggests that true early morning specimens were obtained in most cases. The concentrations were not corrected to take account of specific gravity as the validity of this practice is uncertain (Goldwater, 1964; Jacobs et al., 1964).

The present results are in good agreement with those obtained during the past decade in other countries (Tables 2 and 3 ). They suggest that occupational exposure to mercury is slightly less in AHA

Table 1 Urinary mercury concentrations in Area Health Authority and National Health Service dentists and dental surgery assistants (DSAs)

\begin{tabular}{|c|c|c|c|c|c|c|c|c|c|c|}
\hline \multicolumn{6}{|c|}{$\begin{array}{l}\text { Personnel } \\
\text { Area Health Authority }\end{array}$} & \multicolumn{5}{|c|}{ National Health Service } \\
\hline & \multirow[t]{2}{*}{$n$} & \multirow{2}{*}{$\begin{array}{c}\text { Urinary } \\
\text { mercury } \\
\text { (nmolll) } \\
\text { Mean }\end{array}$} & \multirow[b]{2}{*}{ Range } & \multicolumn{2}{|c|}{ Number of subjects with } & \multirow[t]{2}{*}{$n$} & \multirow{2}{*}{$\begin{array}{c}\text { Urinary } \\
\text { mercury } \\
(\text { nmol/l) } \\
\text { Mean }\end{array}$} & \multirow[b]{2}{*}{ Range } & \multicolumn{2}{|c|}{ Number of subjects with } \\
\hline & & & & $>150 \mathrm{nmol} / \mathrm{l}$ & $>500 \mathrm{nmol} / \mathrm{l}$ & & & & $>150 \mathrm{nmol} / \mathrm{l}$ & $>500 \mathrm{nmol} / \mathrm{l}$ \\
\hline $\begin{array}{l}\text { Dentists } \\
\text { DSAs }\end{array}$ & $\begin{array}{l}28 \\
34\end{array}$ & $\begin{array}{l}76 \cdot 9 \\
97 \cdot 5\end{array}$ & $\begin{array}{l}25-115 \\
25-455\end{array}$ & $\begin{array}{l}1 \\
7\end{array}$ & $\begin{array}{l}0 \\
0\end{array}$ & $\begin{array}{l}21 \\
28\end{array}$ & $\begin{array}{l}110 \cdot 7 \\
191 \cdot 3\end{array}$ & $\begin{array}{l}25-500 \\
25-940\end{array}$ & $\begin{array}{r}3 \\
10\end{array}$ & $\begin{array}{l}1 \\
4\end{array}$ \\
\hline
\end{tabular}




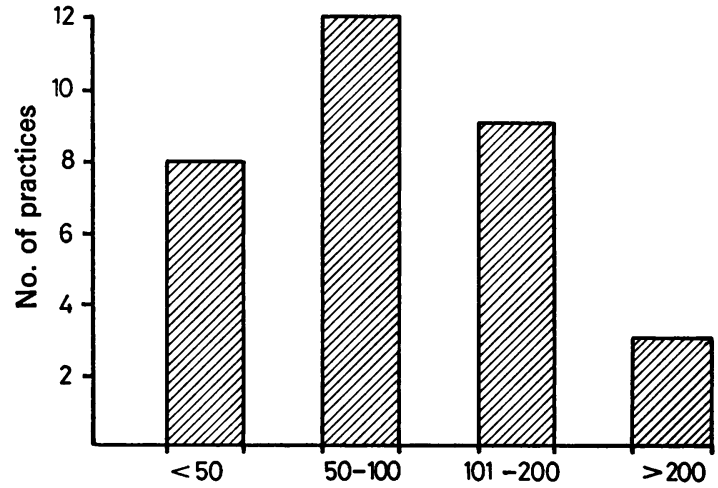

$\mathrm{Hg}(\mathrm{nmol} / 1)$

Fig. 3 Urinary mercury concentrations: practice averages.

dentists than in NHS practitioners, a finding which is no doubt related to the greater amount of time spent by the latter on conservation work. No formal attempt has been made to relate urinary mercury concentrations to workload, a procedure which has proved unrewarding in other studies (Buchwald, 1972).

There is some dispute about the upper limit of urinary mercury excretion in non-occupationally exposed workers but a reasonable figure would seem to be $100-125 \mathrm{nmol} / \mathrm{l}(20-25 \mu \mathrm{g} / \mathrm{l})$, as suggested by Goldwater (1964). Battistone et al. (1973) found that the urinary mercury concentration in nonoccupationally exposed workers did not exceed $85 \mathrm{nmol} / \mathrm{l}(17 \mu \mathrm{g} / \mathrm{l})$, but Taylor and Marks (1973) suggested a rather higher upper limit of around $200 \mathrm{nmol} / \mathrm{l}(40 \mu \mathrm{g} / \mathrm{l})$; and Stewart et al. (1977) found a range of $0-157 \mathrm{nmol} / 24 \mathrm{hr}$ with a median value of $72 \mathrm{nmol} / 24 \mathrm{hr}(14 \mu \mathrm{g} / 24 \mathrm{hr})$. Taking an upper limit of normal of $150 \mathrm{nmol} / 1(30 \mu \mathrm{g} / 1)$, it is clear that a substantial proportion $(8.2 \%$ of dentists, $27.4 \%$ of DSAs) of the dental personnel in this and other studies show evidence of increased mercury absorption, indeed this is only to be expected in view of their occupation. Nevertheless, no worker showed clinical evidence of mercury intoxication, and the urine concentrations were all below the level at which clinical manifestations of mercurialism become likely.

Noe (1959) suggested a danger level of 1500 $\mathrm{nmol} / \mathrm{l}(300 \mu \mathrm{g} / \mathrm{l})$; and West and $\operatorname{Lim}(1968)$ found that, out of a group of 35 cinnabar miners with urinary mercury concentrations in excess of $1500 \mathrm{nmol} / 1,23$ had symptoms of mercury poisoning. Conversely, Wallach (1972) reported a case in which the urinary mercury excretion was in excess of $3000 \mathrm{nmol} / \mathrm{l}$ $(600 \mu \mathrm{g} / \mathrm{l})$ without any evidence of mercury intoxication. Allowing for the 'wide fluctuations which occur from hour to hour and from day to day' (Goldwater, 1964), it is probably reasonable to assume that clinical evidence of mercury poisoning is unlikely to occur when the urinary concentration is below $1500 \mathrm{nmol} / \mathrm{l}$. All workers in the present study

Table 2 Urinary mercury. Results of other studies: dentists

\begin{tabular}{|c|c|c|c|c|c|}
\hline Authors & Country & $\begin{array}{l}\text { Number of } \\
\text { dentists }\end{array}$ & Range (nmolll $)^{*}$ & $\%>500$ nmolll* & Comments \\
\hline $\begin{array}{l}\text { Joselow et al., } 1968 \\
\text { Cuzacq et al., } 1971 \\
\text { Buchwald, } 1972\end{array}$ & $\begin{array}{l}\text { USA } \\
\text { USA } \\
\text { Canada }\end{array}$ & $\begin{array}{l}50 \\
74 \\
21\end{array}$ & $\begin{array}{l}0-770 \\
0-1100 \\
?\end{array}$ & $\begin{array}{l}6 \cdot 0 \\
4 \cdot 0 \\
9 \cdot 5\end{array}$ & $\begin{array}{l}\text { Casual, not early morning samples } \\
\text { Casual, not early morning samples } \\
\text { Pooled daytime samples corrected } \\
\text { to SG } 1.024\end{array}$ \\
\hline $\begin{array}{l}\text { Gronka } \text { et al., } 1970 \\
\text { Battistone } \text { et al., } 1973 \\
\text { Schneider, } 1974 \\
\text { Brooks and Allingham, } 1974 \\
\text { Present study }\end{array}$ & $\begin{array}{l}\text { USA } \\
\text { USA } \\
\text { USA } \\
\text { New Zealand } \\
\text { UK }\end{array}$ & $\begin{array}{l}16 \\
38 \\
76 \\
26 \\
49\end{array}$ & $\begin{array}{c}0-1600 \\
0-610 \\
10-550 \\
0-320 \\
0-500\end{array}$ & $\begin{array}{l}18 \cdot 8 \\
5 \cdot 3 \\
? \\
0 \\
2 \cdot 0\end{array}$ & $\begin{array}{l}\text { Military dental personnel } \\
\text { Pooled daytime samples }\end{array}$ \\
\hline
\end{tabular}

* Figures approximate because of conversion to SI units.

Table 3 Urinary mercury. Results of other studies: DSAs

\begin{tabular}{|c|c|c|c|c|c|}
\hline Authors & Country & Number & Range (nmol/l)* & $\%>500 \mathrm{nmol} / \mathrm{l}^{*}$ & Comments \\
\hline $\begin{array}{l}\text { Cuzacq et al., } 1971 \\
\text { Buchwald, } 1972\end{array}$ & $\begin{array}{l}\text { USA } \\
\text { Canada }\end{array}$ & $\begin{array}{l}65 \\
21\end{array}$ & $?^{0-1800}$ & $\begin{array}{l}10 \cdot 8 \\
16 \cdot 7\end{array}$ & $\begin{array}{l}\text { Casual, not early morning samples } \\
\text { Pooled daytime samples corrected } \\
\text { to SG } 1.024\end{array}$ \\
\hline $\begin{array}{l}\text { Gronka } \text { et al., } 1970 \\
\text { Battistone } \text { et al., } 1973 \\
\text { Schneider, } 1974 \\
\text { Brooks and Allingham, } 1974 \\
\text { Present study }\end{array}$ & $\begin{array}{l}\text { USA } \\
\text { USA } \\
\text { USA } \\
\text { New Zealand } \\
\text { UK }\end{array}$ & $\begin{array}{r}7 \\
32 \\
73 \\
28 \\
62\end{array}$ & $\begin{array}{l}? \\
0-485 \\
10-1500 \\
0-1100 \\
0-940\end{array}$ & $\begin{array}{l}14 \cdot 3 \\
0 \\
? \\
3 \cdot 6 \\
8 \cdot 1\end{array}$ & $\begin{array}{l}\text { Military dental personnel } \\
\text { Pooled daytime samples }\end{array}$ \\
\hline
\end{tabular}

*Figures approximate because of conversion to SI units. 
were safely below this level.

In a similar recent Employment Medical Advisory Service investigation in 19 Newcastle dental surgeries (Bell, D., unpublished) it was found that, out of a total of 26 dentists and 26 DSAs, none had a urinary mercury concentration greater than $290 \mathrm{nmol} / 1$ $(58 \mu \mathrm{g} / \mathrm{l})$. Mercury-in-air measurements were all below the TLV $\left(0.05 \mathrm{mg} / \mathrm{m}^{3}\right)$, although personnel with the higher urinary levels tended to be from the surgeries with the higher air levels.

It has been suggested that dental personnel should be regularly monitored biologically by means either of urinary mercury estimations (Schneider, 1974), or of mercury levels in nails and hair (Lenihan et al., 1973). The present results do not, however, support this contention because, with the exception of one DSA, the high individual results in the present survey can all be readily explained by neglect of the basic hygienic measures which are known to be necessary to prevent mercury becoming a health hazard in dental surgeries. With the proviso that this is a relatively small survey in one part of the country only, the results suggest that simple personal and environmental hygienic precautions are all that is necessary to prevent a hazard to health from the use of mercury in dental surgeries. They certainly do not support an American viewpoint (McCord, 1961) that 'over the land (USA) at all times some thousands of dentists are the victims of mercury poisoning in varying degrees of severity'.

\section{References}

Battistone, O. C., Sammons, D. W., and Miller, R. A. (1973). Mercury excretion in military dental personnel. Oral Surgery, Oral Medicine and Oral Pathology, 35, 47-52.

Brooks, J. M., and Allingham, P. M. (1974). Mercury hazards in dentistry. New Zealand Dental Journal, 70, 166-180.

Buchwald, H. (1972). Exposure of dental workers to mercury. American Industrial Hygiene Association Journal, 33, $492-$ 502.

Central Unit on Environmental Pollution. (1976). Environmental Mercury and Man. Pollution Paper No. 10. HMSO: London.

Cook, T. A., and Yates, P. O. (1969). Fatal mercury intoxication in a dental surgery assistant. British Dental Journal, 127, 553-555.

Cuzacq, G., Comproni, E. M., and Smith, H. L. (1971). Mercury contamination in the dental office. Journal of the Massachusetts Dental Society, 20, 254-261.

Editorial. (1971). Mercury hygiene. Journal of the American Dental Association, 82, 464.
Goldwater, L. J. (1964). Occupational exposure to mercury. Journal of the Royal Institute of Public Health, 27, 279-285.

Gronka, P. A., Bobkoskie, R. L., Tomchick, G. J., Bach, F., and Rakow, A. B. (1970). Mercury vapour exposures in dental offices. Journal of the American Dental Association, 81, 923-925.

Iyer, K., Goodgold, J., Eberstein, A., and Berg, P. (1976). Mercury poisoning in a dentist. Archives of Neurology, 33, 788-790.

Jacobs, M. B., Ladd, A. C., and Goldwater, L. J. (1964). Absorption and excretion of mercury in man: VI. Significance of mercury in urine. Archives of Environmental Health, 9, 454-463.

Joselow, M. M., Goldwater, L. J., Alvarez, A., and Herndon, J. (1968). Absorption and excretion of mercury in man: XV. Occupational exposure among dentists. Archives of Environmental Health, 17, 39-43.

Lenihan, J. M. A., Smith, H., and Harvey, W. (1973). Mercury hazards in dental practice. British Dental Journal, 135, 365-369.

McCord, C. P. (1961). Mercury poisoning in dentists. Industrial Medicine and Surgery, 30, 554.

Magos, L., and Cernik, A. A. (1969). A rapid method for estimating mercury in undigested biological samples. British Journal of Industrial Medicine, 26, 144-149.

Mantyla, D. G., and Wright, O. D. (1976). Mercury toxicity in the dental office: a neglected problem. Journal of the American Dental Association, 92, 1189-1194.

Merfield, D. P., Taylor, A., Gemmell, D. M., and Parrish, J. A. (1976). Mercury intoxication in a dental surgery following unreported spillage. British Dental Journal, 141, 179-186.

Molyneux, M. K. B. (1966). Observations of the excretion rate and concentration of mercury in urine. Annals of Occupational Hygiene, 9, 95-102.

Nixon, G. S., and Rowbotham, T. C. (1971). Mercury hazards associated with high-speed mechanical amalgamators. British Dental Journal, 131, 308-311.

Noe, F. E. (1959). Mercury as a potential hazard in medical laboratories. New England Journal of Medicine, 261, 10021006.

Schneider, M. (1974). An environmental study of mercury contamination in dental offices. Journal of the American Dental Association, 89, 1092-1098.

Stewart, W. K., Guirgis, H. A., Sanderson, J., and Taylor, W. (1977). Urinary mercury excretion and proteinuria in pathology laboratory staff. British Journal of Industrial Medicine, 34, 26-31.

Taylor, A., and Marks, V. (1973). Measurement of urinary mercury excretion by atomic absorption in health and disease. British Journal of Industrial Medicine, 30, 293-296.

Vostal, J. J., and Clarkson, T. W. (1973). Mercury as an environmental hazard. Journal of Occupational Medicine, 15, 649-656.

Wallach, L. (1972). Aspiration of elemental mercuryevidence of absorption without toxicity. New England Journal of Medicine, 287, 178-179.

West, I., and Lim, J. (1968). Mercury poisoning among workers in California's mercury mills. Journal of Occupational Medicine, 10, 697-701. 